\title{
CLINICAL AND EPIDEMIOLOGICAL FEATURES OF ORAL CANCER IN A MEDICAL SCHOOL TEACHING HOSPITAL FROM 1994 TO 2002: INCREASING INCIDENCE IN WOMEN, PREDOMINANCE OF ADVANCED LOCAL DISEASE, AND LOW INCIDENCE OF NECK METASTASES
}

\author{
Marcelo D. Durazzo, Carlos Eugenio Nabuco de Araujo, José de Souza Brandão \\ Neto, André de Souza Potenza, Pedro Costa, Flávio Takeda, Cristina Bianchi, \\ Marcos R. Tavares, Gilberto de Britto e Silva Filho, and Alberto R. Ferraz
}

Durazzo MD, Araújo CEN de, Brandão Neto J de S, Potenza A de S, Costa P, Takeda F., et al. Clinical and epidemiological features of oral cancer in a medical school teaching hospital from 1994 to 2002: increasing incidence in women, predominance of advanced local disease, and low incidence of neck metastases. Clinics 2005;60(4): 293-8.

PURPOSE: Description of clinical and epidemiological characteristics of patients who underwent surgery for oral cancer in a Medical School Teaching Hospital, and determination of differences with respect to other institutions and/or periods of time.

METHOD: The charts of patients undergoing surgery for oral cancer from 1994 to 2002 were reviewed. Data were collected in a spreadsheet in order to analyze clinical and epidemiological features..

RESULTS: A total of 374 patients having undergone 406 operations was identified. Their ages varied from 14 to 94 years (mean $=57.4$ years), with 255 men $(68.2 \%)$, and 295 out 366 Caucasian $(80.6 \%)$. A majority had tumors of the tongue and/ or floor of mouth $(55.6 \%)$, while $20.3 \%$ had lip cancer. Squamous cell carcinoma was found in $90.3 \%$, and glandular carcinoma in $4 \%$. T4 tumors in $39.6 \%$, Tis or T1 lesions in $15.2 \%$ of all patients. Nearly $62 \%$ had no regional metastases, and the relative incidence in young patients (40 years or younger) reached $8.6 \%$.

CONCLUSION: In spite of the predominance of locally advanced tumors, a majority of patients had no neck metastases. The $31.8 \%$ incidence in females indicates an increasing incidence of oral cavity cancer among women when compared to previous periods at the same institution.

KEYWORDS: Head and neck neoplasms. Mouth neoplasms. Neoplasm metastasis. Population at risk. Epidemiology.

Cancer of the oral cavity represents $2.6 \%$ of all malignancies affecting the Brazilian population according an estimate from the Brazilian National Cancer Institute (INCa) for 2003. Oral cancer is the eighth most common cancer in Brazil and occupies the sixth place when only men are considered. Regarding mortality, a total of $2.8 \%$ of deaths by cancer was due to malignancies in the mouth, which places oral cancer in the ninth place for mortality among all malignant tumors. ${ }^{1}$

Head and Neck Service, Hospital das Clínicas, Faculty of Medicine, University of São Paulo - São Paulo/SP, Brazil.

E-mail: mddurazzo@aol.com

Received for publication on January 12, 2005.

Accepted for publication on April 29, 2005.
Despite this marked importance of oral cancer, its main risk factors, namely the tobacco smoking and alcohol consumption, are well known and may be avoided., ${ }^{2,3,4}$ In addition to being primarily preventable through through avoidance of these risk factors, oral malignancies may be diagnosed in early stages with no major difficulties, making these tumors also suitable to secondary prevention. In fact, the oral cavity may be easily examined by health care professionals such as doctors, dentists, nurses, and speech therapists. ${ }^{5}$ The individual may personally conduct an auto-examination $^{5}$ (during the morning oral hygiene, for example).

In spite of the relative ease of mouth examination, the systematic examination of the oral cavity by health care profes- 
sionals and oral auto-examination have not been routinely and widely employed and have received little attention from both professionals and patients. As a result, advanced cancer predominates in the services of Head and Neck Surgery, Dermatology, Oncology, and Dentistry in hospitals of tertiary and quaternary attention where most patients have their diagnosis of oral cancer. ${ }^{3,4,6,7}$ The treatment of advanced head and neck cancer including oral cancer is carried out in Head and Neck Surgery and Oncology services and will have worse results in terms of survival, function, and cosmesis when compared to results obtained after treatment of initial disease. ${ }^{8-12}$

Regarding oral cancer in its initial presentations, it seems to be more reasonable (both in terms of diagnostic and therapeutic approaches) to determine which are the individuals and/or populations most frequently affected in order to delineate strategies for secondary prevention. It also appears that a strategy for primary prevention (such as spreading information about the need to avoid the main risk factors) allows health professionals and individuals at risk to be more cautious about the disease and, consequently, contributes to the diagnosis of oral cancer in early stages.

The aim of the present study is to describe clinically and epidemiologically the population of patients who underwent surgery for oral cancer in our service from 1994 to 2002, and to determine whether there are differences when the profile of this group of patients is compared to other series from the same service in previous periods and to other tertiary and quaternary attention institutions in 2 major Brazilian cities. Our service is responsible for the treatment of patients coming from the entire country with cancer of the oral cavity at any stage, including patients who require high complexity treatment modalities.

\section{PATIENTS AND METHODS}

The charts of all patients undergoing surgery for oral cancer from 1994 to 2002 were retrospectively reviewed. Some of them underwent other treatment modalities preoperatively or postoperatively. Demographics (age, gender, and ethnicity), habits (tobacco smoking and alcohol consumption) and clinical data (symptoms, duration of symptoms, location of the tumor, histologic type, TNM stage, and pTNM stage) were collected in a spreadsheet and analyzed.

\section{RESULTS}

From 1994 to 2002, 374 patients with oral cancer underwent 406 surgical procedures. Their ages varied from 14 to 94 years $($ mean $=57.4$ years $)$. Only $8.6 \%$ of patients were 40 years old or younger. There were 119 (31.8\%) women. A total of $295(80.6 \%)$ patients were Caucasians.
Regarding habits, tobacco smoking was identified in 202 of 250 patients $(80.8 \%)$. Alcohol consumption history could be retrieved in 138 of 244 patients $(56.6 \%)$.

The period of time between the appearance of the first symptoms to the first visit to the Service varied from 10 days to 20 years. The mean duration of symptoms was 14.1 months. The most frequent symptoms were the presence of a lesion in the mouth and local pain (Table I).

Table 1 - Prevalence of symptoms at the time of diagnosis/ treatment

\begin{tabular}{lcc}
\hline Symptoms & $\mathrm{n}=305$ & Prevalence \\
\hline Oral lesion & 268 & $87.9 \%$ \\
Oral pain & 108 & $35.4 \%$ \\
Weight loss & 40 & $13.1 \%$ \\
Enlarged neck node & 29 & $9.5 \%$ \\
Bleeding & 17 & $5.6 \%$ \\
Dysphagia & 14 & $4.6 \%$ \\
Odynophagia & 9 & $2.9 \%$ \\
Otalgia & 8 & $2.6 \%$ \\
Trismus & 8 & $2.6 \%$ \\
Halitosis & 7 & $2.3 \%$ \\
Loss of tongue mobility & 5 & $1.6 \%$ \\
Sensation of foreign body & 3 & $1.0 \%$ \\
Pruritus & 1 & $0.3 \%$ \\
\hline
\end{tabular}

Squamous cell carcinoma was found in 317 of 351 patients $(90.3 \%)$ ). Glandular carcinoma (adenoid cystic carcinoma, adenocarcinoma and mucoepidermoid carcinoma) was found in 14 individuals (4\%), and verrucous carcinoma in $4(1.1 \%)$.

The most frequent sites of the primary tumors were the tongue, the floor of the mouth, and the lips. Figure 1 shows the distribution of patients according to the site of the primary tumor.

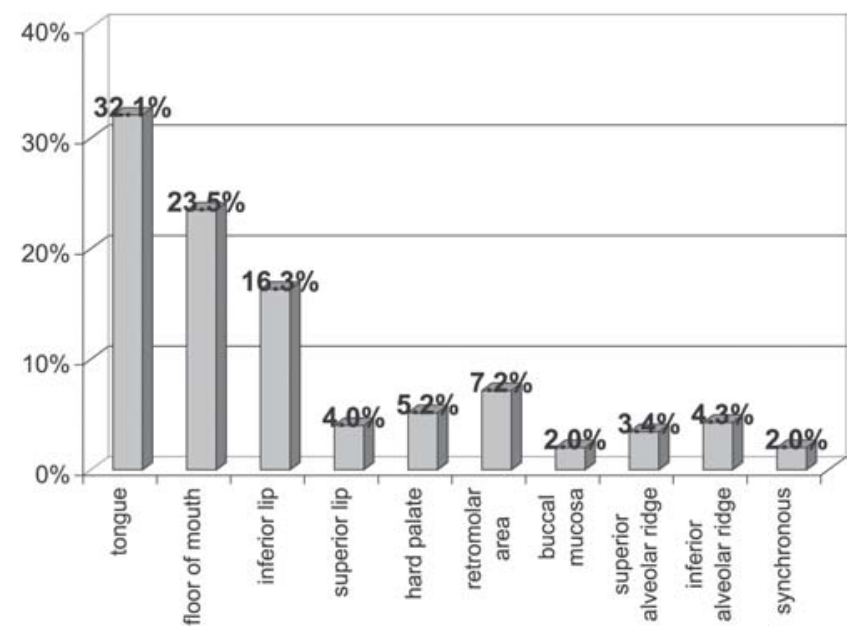

Figure 1 - Distribution of tumors according to their location in the oral cavity $(n=349)$. Synchronous refers to 2 or more tumors ( 1 in the oral cavity and another in any site of the upper aerodigestive tract) 
Regarding the stage of disease, the majority of the patients had advanced local disease. T4 lesions were found in $39.6 \%$. Prior to the pathology report, 153 of 298 patients (51.3\%) were classified in stage IV according to the TNM Classification, and only $14.5 \%$ were classified as having stage 0 or I disease. After the macroscopic and microscopic pathologic study, $16.8 \%$ were classified in stages 0 and I. The majority of patients $(61.6 \%)$ did not present regional metastases. Figures 2, 3, and 4 illustrate the distribution of patients according to $\mathrm{T}$ classification, TNM stage, and pTNM stage.

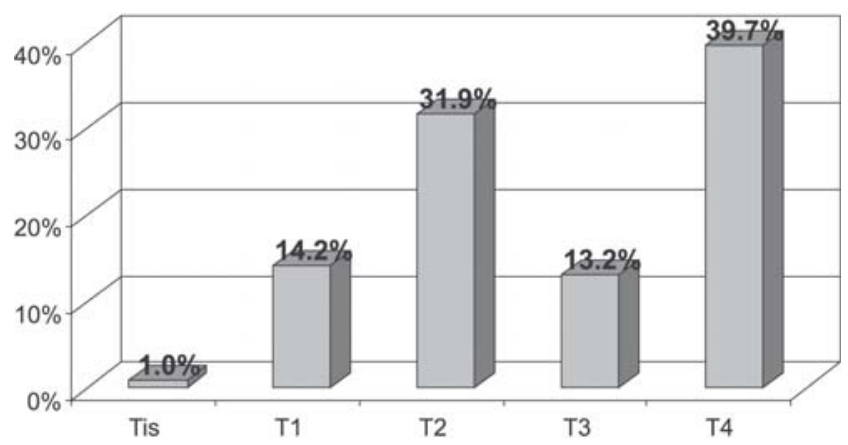

Figure 2 - Distribution of patients according to $\mathrm{T}$ Classification stage at initial presentation $(n=295)$

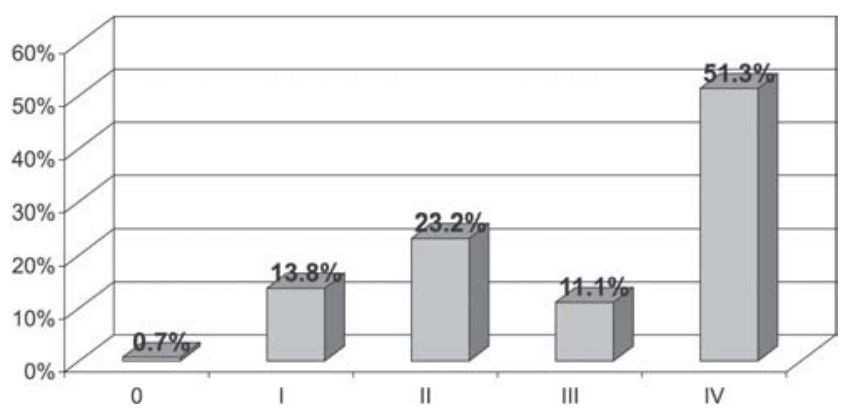

Figure 3 - Distribution of patients according to TNM System Classification stage at the time of diagnosis $(n=298)$

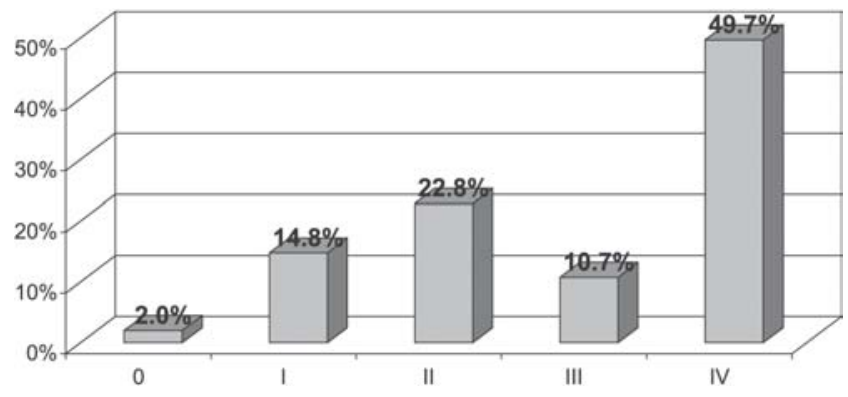

Figure 4 - Distribution of patients according to pTNM System Classification stage after pathologic examination $(n=149)$

\section{DISCUSSION}

During the 9-year period of this study, 374 patients underwent surgery for oral cancer (average of 41.5 cases per year).
In 1998, Araujo Filho et al. ${ }^{6}$ reported 54 patients operated on for oral cancer at the same institution during a period of 10 years. Kawata ${ }^{13}$, in 2004, analyzed retrospectively 141 records of patients with mouth cancer admitted for surgical treatment between 1985 and 1997, also in the same service. These data reveal an evident increase in the number of cases of oral cancer undergoing surgery in our service during recent years. In another tertiary service in the same city, Fardin et al. ${ }^{14}$ reported 1,440 mouth cancer patients seen between 1977 and 1998 (average of 65.5 cases/year). This greater incidence in their institution may be explained by the inclusion in their series of patients that had never undergone surgical treatment. Barbosa et al. ${ }^{15}$ published a study from Hospital do Cancer of the INCa, in Rio de Janeiro, with 258 patients treated between 1975 and 1980 (average 43 cases/year) representing a tertiary service in that city. Analyzing these reports, we conclude that close to 40 or 50 patients are treated in main Brazilian specialized head and neck services every year.

The most frequent age at presentation was between 50 and 60 years, which underwent no significant variations over time in our service. In the study by Barbosa et al., ${ }^{15}$ the highest incidence occurred between 40 and 50 years. Although Fardin et al. ${ }^{14}$ did not publish the average age at presentation, $52 \%$ of their patients were between 50 and 65 years of age. Young patients were considered to be those 40 years of age or less and comprised $8.6 \%$ of all individuals in our series.

The fact that oral cancer affects many more men than women may be observed in all series from western countries ${ }^{2,4}$. In the present study, $31.8 \%$ of all patients were women. Araujo Filho et al. ${ }^{6}$ and Fardin et al. ${ }^{14}$ found less than $20 \%$ women in their series. Barbosa et al. ${ }^{15}$ reported $26.4 \%$, and Kawata ${ }^{13}$ $25.5 \%$ women in their studies. All of these 4 studies were carried out some time ago, 2 of them ${ }^{6,13}$ being from our service. This suggests that we have had a relative increase in the incidence of oral cancer in women, at least in our hospital. The percentage of women reported in the present paper is uncommonly high if compared not only with the above mentioned studies, but also to the $27.1 \%$ estimation for Brazilian women for the year 2003. ${ }^{1}$ This increase is attributed by most authors to the increasing number women who smoke in the general population $^{2,4}$. In addition, this increase of smoking has led women to develop more smoke-related diseases/conditions in recent decades. In 2004, Kazerouni et al. found an increase of $382 \%$ in mortality for chronic obstructive pulmonary disease in North-American women between 1968 and 1999 much more compared to the increase of $27 \%$ in men. In addition, the authors observed the same tendency in the mortality for lung cancer: an increase of $266 \%$ in women versus $15 \%$ in men. ${ }^{16}$ There is also evidence that women are more susceptible to the effects of smoking than men, at least regarding oral ${ }^{17}$, lung ${ }^{17}$ and bladder ${ }^{18}$ cancers. 
Caucasians comprised $80.6 \%$ of our patients. This is comparable to $82.6 \%$ found by Kawata ${ }^{13}$ and $88 \%$ of Caucasians and Asians reported by Fardin et al. ${ }^{14}$ in their studies, which were also carried out in the city of São Paulo. However, differentiation according race seems to be of little relevance in the studied population because there is great race miscegenation in the Brazilian population, thus turning race definition into a quite subjective exercise by the physician. Nevertheless, the data suggest a predominance of oral cancer in Caucasians. In this series this may be also explained by the inclusion of lip cancer in the study population. Lip cancer has a marked predominance in Caucasians and is associated with exposure to solar irradiation.

Considering the medical records analyzed, lifestyle habits were registered in only $70 \%$, indicating that the 2 main risk factors for mouth cancer were often ignored by physicians. Smoking was observed in $80.8 \%$ of our cases for which lifestyle habits were recorded. Araujo Filho et al. ${ }^{6}$ found $88.9 \%$ smokers, and Kawata ${ }^{13}$ reported $82.3 \%$ smokers, both data from our service. Fardin et al. ${ }^{14}$ and Barbosa et al. ${ }^{15}$ also reported $88.2 \%$ and $89.9 \%$ smokers, respectively. This shows that smoking is the most marked risk factor in any sample of mouth cancer patients. Alcohol consumption was observed in $56.6 \%$ of our cases, while Araujo Filho et al. ${ }^{6}$ reported 65\%, Kawata ${ }^{13}$ $53.2 \%$, and Fardin et al. ${ }^{14} 75 \%$. Barbosa et al. ${ }^{15}$ reported $60.5 \%$ of smokers and alcohol beverage consumers in their series. These data suggest that alcohol consumption is a frequent habit of oral cancer patients, but less prevalent than smoking. The literature shows the extensive relationship between smoking and drinking, probably acting in synergism, with mouth cancer incidence. However, we found that only $70 \%$ of the charts had a reference to the patient's lifestyle habits, in spite of the fact that recording them is absolutely imperative and of major importance for adequately characterizing the sample and the exposure of patients to the main external risk factors.

Regarding the complaints, oral lesion $(87.9 \%)$ and local pain $(35.4 \%)$ were the most frequently reported symptoms. Fardin et al. ${ }^{14}$ reported the main complaints as "lesion in the mouth" in $46 \%$ and pain in $18 \%$. Duration of symptoms before diagnosis averaged of 14.1 months, which is higher than that observed by Araujo Filho et al. ${ }^{6}$ from our service, who reported less than 6 months duration of symptoms in $50 \%$ of that sample. A total of $79.6 \%$ of all patients in that series had less than 1 year of symptoms. Fardin et al. ${ }^{14}$ reported a duration of symptoms prior to diagnosis of 6.3 and 9.1 months on average, depending on the anatomic site of the tumor. In Rio de Janeiro, Azevedo et al. ${ }^{19}$ found an average of 6 months of symptoms before diagnosis in 170 patients seen for oral and oropharyngeal cancer between March 1994 and September 1995. These data show that the average duration of symptoms before diagnosis in our service is high and is increasing through time. Since it is well know that a long duration of symptoms is related to a worse prognosis (because it is closely related to the stage of disease), every effort should be employed in primary and secondary prevention, the latter aiming to reduce the time to diagnosis and treatment. Professionals and affected individuals must receive information aimed at making them more conscious of the risk of oral cancer in order to involve the head and neck surgery and oncology services earlier in the development of treatment.

In the present series, $55.6 \%$ of patients had cancer of the tongue and floor of the mouth, outnumbering other oral anatomic sites (lips, hard palate, retromolar area, superior and inferior alveolar ridge, and buccal mucosa). Fardin et al. ${ }^{14}$ found $71.8 \%$ and Kawata ${ }^{13}$ reported $80.2 \%$ tumors of the tongue and floor of mouth. However, these authors did not include lip tumors in their studies, which represented $20 \%$ of tumors in this series. Squamous cell carcinoma was the most frequent histologic type, and was present in $90.3 \%$ of all specimens obtained from patients included in this study. Glandular carcinomas were found in $4 \%$ of them. All these numbers agree with other Brazilian ${ }^{4,20}$ and with foreign ${ }^{21,22}$ studies.

Local advanced disease was more frequent than initial disease (39.7\% for T4 versus $15.2 \%$ for T1 plus Tis). Similarly, $51.3 \%$ of mouth cancer patients were clinically classified in stage IV according to TNM Classification. After surgery and histopathology analysis, $49.7 \%$ of all patients were classified as stage IV (pTNM Classification). These numbers show that half of all patients, demanded aggressive treatment and a multidisciplinary approach. Despite all efforts, oncologic, aesthetic, and functional results after treating this subgroup were usually poor, especially when compared to those obtained in patients with initial disease. The evaluation of these results is beyond the scope of this paper (which aims essentially to characterize our patients). The results presented in this study are comparable to other series in major Brazilian cities. Fardin et al. ${ }^{14}$ reported $57 \%$ of their patients with stage IV disease in a sample from the same population of São Paulo. Barbosa et al. ${ }^{15}$ observed $40.7 \%$ patients with stage IV disease in Rio de Janeiro. Taking these figures into account, it is important to reinforce the urgency of making efforts directed to secondary prevention strategies in order to diagnose and treat oral cancer at earlier stages, thus achieving better prognosis and quality of life for patients. ${ }^{5,12}$

In contrast to the large percentage of patients with advanced disease, patients with initial disease (Stage 0 and I) comprised $15.2 \%$ in the present series, which was higher than the numbers from Fardin et al. ${ }^{14}$ and Barbosa et al. ${ }^{15}$, who reported 6\% in São Paulo and $4.3 \%$ in Rio de Janeiro, respectively. In our institution, the number of patients with initial oral cancer has been increasing with time. ${ }^{6,13,20}$ This can be explained by the formation (in 1995) of a student enrolling or- 
ganization devoted to the prevention and treatment of oral cancer in the São Paulo University School of Medicine teaching Hospital where our service is located. Additionally, we receive referrals from an organization founded to study buccal neoplasias at the School of Dentistry in the same University. 3,7 The aim of these organizations may have been partially achieved, since some oral cancer patients have apparently had an earlier access to medical assistance than in the past.

Considering that squamous cell carcinoma (found in $90.3 \%$ of our patients) tends to spread to regional lymph nodes, ${ }^{4,6-11}$ it is amazing that $61.1 \%$ of them did not have regional metastases (N0), confirming previous reports from our service. ${ }^{6,20}$ The absence of regional metastases is a positive prognostic factor and is associated with a decrease of $50 \%$ in mortality. Carvalho et al. ${ }^{23}$ reported $50.1 \%$ N0 necks in another large series from a tertiary hospital in São Paulo. This seems to be a low incidence considering the large number of patients with local advanced disease. Some authors do not detail the incidence of regional metastases in their papers, merely reporting the TNM staging.

\section{CONCLUSIONS}

The profile of patients with oral cancer in our service is similar in several aspects to those presented by other investigators in Brazil and abroad. There is a marked predominance of men and Caucasians around the fifth and sixth decades of life. Also, there is a predominance of tobacco users, and more than half of the patients have an alcohol intake history. Regarding the tumors, squamous cell carcinoma is the most frequent histologic type. The most frequent sites are the tongue and the floor of the mouth.

The sample of patients in this study presented some differences to those of other studies, including the high and increasing incidence of oral cancer in women and the low incidence of regional metastases (even with the marked predominance of advanced local disease).

The fact that half of the patients in this study presented with advanced oral cancer (stage IV) illustrates that prevention and early-detection strategies are urgently needed. The approaches might include the continuous education of health care professionals (i.e., the dissemination of the systematic examination of the oral cavity and emphasis on the importance of adequate reporting habits in patients' charts) and information to general population (ie, spreading concepts like how to conduct an oral auto-examination, how tobacco smoking and alcohol drinking may be hazardous to the health, and the importance of seeing a health professional when a suspicious lesion appears in the mouth).

\section{RESUMO}

Durazzo MD, Araújo CEN de, Brandão Neto J de S, Potenza A de S, Costa P, Takeda F., et al. Características clínicas e epidemiológicas do câncer da boca em hospital-escola de 1994 a 2002: aumento da incidência em mulheres, predomínio de doença local avançada e baixa incidência de metástases regionais. Clinics 2005;60(4): 293-8.

OBJETIVO: Caracterizar epidemiológica e clinicamente a população atendida por câncer de boca em hospital-escola de atenção terciária e quaternária e verificar variações em relação a outras casuísticas e períodos.

MÉTODO: Procedeu-se à revisão dos prontuários dos operados por câncer oral de 1994 a 2002. As características clínicas e epidemiológicas foram colocadas em planilhas e analisadas.

RESULTADOS: Foram identificados 374 portadores de câncer da boca que foram submetidos a 406 operações. A idade dos doentes variou de 14 a 94 anos (média $=57,4$ anos). Duzentos e cinqüenta e cinco eram do gênero masculino (68,2\%). Duzentos e noventa e cinco entre 366 doentes eram caucasianos $(80,6 \%)$. A maioria era portadora de tumores da língua e/ou do soalho da boca (194 entre 349 doentes; 55,6\%), e 71 (20,3\%) tinham tumores dos lábios. O carcinoma epidermóide foi encontrado em 90,3\% e carcinomas glandulares em 4\%. Os tumores T4 estavam presentes em 39,6\% dos doentes; 15,2\% tinham lesões Tis ou T1. Quase $62 \%$ dos pacientes não tinham metástases cervicais. A incidência relativa em jovens (com até 40 anos de idade) atingiu 8,6\%.

CONCLUSÃO: Apesar dos achados freqüentemente referidos na literatura terem se confirmado (como o predomínio de lesões avançadas localmente), a maioria dos doentes não apresentava metástases cervicais. Acima do observado em outras casuísticas, os $31,8 \%$ de mulheres na presente casuística indica a preocupante e crescente incidência no gênero feminino.

UNITERMOS: Câncer da boca. Neoplasias de cabeça e pescoço. Metástase. Epidemiologia. Características da População. 


\section{REFERENCES}

1. Brasil. Ministério da Saúde. Instituto Nacional de Câncer. Estimativas da incidência e mortalidade por câncer. Rio de Janeiro: INCA; 2003.

2. Tavares MR, Noma RK. Epidemiologia e fatores de risco do câncer da cavidade oral. Rev Med. 1997;76:256-9.

3. Vanderlei FAB, Pereira FC, Barreto RL, Matsunaga P, Durazzo MD, Tavares MR, et al. Três anos de atividades da Liga de Prevenção e Controle do Câncer da Cavidade Oral. Rev Med. 1998;77:179-82.

4. Franco EL, Kowalski LP, Oliveira BV, Curado MP, Pereira RN, Silva ME, et al. Risk factors for oral cancer in Brazil: a casecontrol study. Int J Cancer 1989;43:992-1000.

5. Durazzo MD. Detecção precoce e prognóstico do câncer da boca. In: Comitê de Fonoaudiologia em Cancerologia da Fundação Oncocentro de São Paulo. Fonoaudiologia em Cancerologia 2.000. São Paulo: FOSP; 2000. p. 32-7.

6. Araújo Filho VJF, Carlucci Junior D, Sasaki SU, Montag E, Azato FN, Cordeiro AC, et al. Perfil da incidência do câncer oral em um hospital geral de São Paulo. Rev Hosp Clin Fac Med Sao Paulo. 1998;53:110-3.

7. Durazzo MD. Liga de Prevenção e Controle do Câncer da Cavidade Oral: Abordagem multidisciplinar do câncer oral em hospital-escola. In: Comitê de Fonoaudiologia em Cancerologia da Fundação Oncocentro de São Paulo. Fonoaudiologia em Cancerologia 2000. São Paulo: FOSP; 2000. p. 59-61.

8. Durazzo MD, Silva Filho GB. Tratamento do câncer da cavidade oral. Rev Med. 1997;76:260-5.

9. Cernea CR. The surgical treatment of oral cavity cancer. In: Johnson JT, Didolkar MS. Head and Neck Cancer - volume III. Amsterdam: Elsevier; 1993. p. 691-6.

10. Shah JP, Lydiatt WM. Buccal mucosa, alveolus, retromolar trigone, floor of mouth, hard palate, and tongue tumors. In: Thawley SE, Panje WR, Batsakis JG, Lindberg RD. Comprehensive Management of Head and Neck Tumors - volume I. $2^{\text {nd }}$ ed. Philadelphia: Saunders; 1999. p. 686-94.

11. Medina JE, Byers RM. Supraomohyoid neck dissection: rationale, indications and surgical technique. Head Neck. 1989;11:111-22.

12. Brasil. Ministério da Saúde. Instituto Nacional do Câncer (INCA). Coordenadoria de Programas de Controle do Câncer (Pro-Onco). Câncer de boca - Manual de detecção de lesões suspeitas. $2^{\mathrm{a}}$ edição. Rio de Janeiro: INCA/Pro-Onco; 1996.
13. Kawata LT. Análise multifatorial de segundo tumor primário em pacientes com carcinoma espinocelular de boca: estudo retrospectivo de 141 casos. Dissertação de Mestrado - Faculdade de Odontologia da Universidade Estadual Paulista - UNESP Campus Araçatuba - 2004

14. Fardin M, Rapoport A, Amar A, Magalhães MR, Latorre MRDO. Fatores de risco no prognóstico do câncer da boca. Estudo de 1440 casos. Rev Bras Cir Cab Pesc. 2004;33:27-33.

15. Barbosa MM, Sá GM, Kligerman J. Câncer da boca. Análise de resultados do tratamento de 258 pacientes do Hospital do Câncer (INCa - RJ). Rev Bras Cir Cab Pesc. 1995;19(2):53-7.

16. Kazerouni N, Alverson CJ, Redd SC, Mott JA, Mannino DM. Sex diferences in COPD and lung cancer mortality trends - United States, 1968-1999. J Womens Health (Larchmt) 2004;13:17-23.

17. Muscat JE, Richie JP Jr, Thompson S, Wynder EL. Gender differences in smoking and risk for oral cancer. Cancer Res. 1996;56:5192-7.

18. Castelao JE, Yuan JM, Skipper PL, Tannenbaum SR, GagoDominguez M, Crowder JS, et al. Gender- and smoking-related bladder cancer risk. J Natl Cancer Inst. 2001;93:538-45.

19. Azevedo ALR, Dias FL, Spada MV, Santos TCRB, Noronha LHR, Kligerman J, et al. Levantamento epidemiológico sobre o câncer da boca e orofaringe do Serviço de Cabeça e Pescoço do Hospital do Câncer - INCa - RJ. Rev Bras Cir Cab Pesc. 1996;20:5-12.

20. Durazzo MD, Tavares MR, Araujo CEN, Brandão Neto JS, Matsunaga P, Potenza AS, et al. Perfil dos portadores de câncer da cavidade oral operados de 1994 a 1998: predomínio de doença local avançada e aumento da incidência de mulheres. Rev Bras Cir Cab Pesc. 2001;25:7-10.

21. Skarsgard DP, Groome PA, Mackillop WJ, Zhou S, Rothwell D, Dixon PF, et al. Cancers of the upper aerodigestive tract in Ontario, Canada, and the United States. Cancer 2000;88:1728-38.

22. Canto MT, Devesa SS. Oral cavity and pharynx cancer incidence rates in the United States, 1975-1998. Oral Oncol. 2002;38:6107.

23. Carvalho MB, Lenzi J, Lehn CN, Fava AS, Amar A, Kanda JL, et al. Características clínico-epidemiológicas do carcinoma epidermóide de cavidade oral no sexo feminino. Rev Ass Med Brasil. 2001;47:208-14. 